\title{
透析患者の生命予後に及ぼす収縮期血圧の影響
}

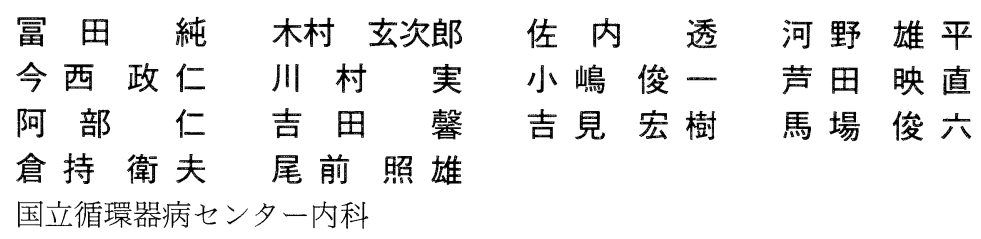

key words : mortality rate, prognosis, cardiovascular morbidity, dialysis, hypertension

〈要旨〉

近年, 透析患者の循環器疾患による死亡率は年々増加してきている. 乥こで, 透析患者の予後を決定する上で, 血 圧がどの程度関与しているか検討した. 1977 年から 1987 年までに当施設で血液透析に導入し, 転院し得た慢性腎不全 患者 195 例（男 123 例，女 72 例，平均年齢 $54 \pm 1$ 歳）について導入期および，維持期（転院時）における血圧と 1990 年 1 月現在における生死との関連を検討した. 3 年以上生存した生存群 132 例と 3 年未満に死亡した死亡群 46 例との

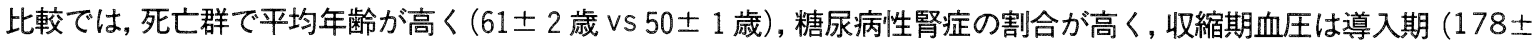
$4 \mathrm{mmHg}$ vs $167 \pm 2 \mathrm{mmHg}$ ), 維持期 (165 $4 \mathrm{mmHg}$ vs $147 \pm 2 \mathrm{mmHg}$ ) とも高值であった。ただし，拡張期血圧に 関しては導入期, 維持期とも両群間に有意差を認めなかった。非糖尿病性腎症例に限ると維持期収縮期血圧のみ死亡 群で有意に高值であった。 そこで, 維持期収縮期血圧に着目し $160 \mathrm{mmHg}$ 以上を HT 群, $160 \mathrm{mmHg}$ 未満を NT 群 とし, 累積生存率を比較検討した。195 例全例でも, 非糖尿病性腎症でも, 糖尿病性腎症例でも HT 群に比し NT 群 で有意に生存率が高值を示した。導入期から維持期に至る収縮期血圧の推移別に, 1. 導入期収縮期血圧が $160 \mathrm{mmHg}$ 以上であったが, 維持期には $160 \mathrm{mmHg}$ 未満に低下した HT-NT 群, 2. 維持期にもなお $160 \mathrm{mmHg}$ 以上を示した HT-HT 群, および 3. 導入期, 維持期を通して $160 \mathrm{mmHg}$ 未満であった NT-NT 群の 3 群に分類し累積生存率を比 較した。HT-NT群はHT-HT群に比し有意に生存率が高くNT-NT 群と有意差のないレベルに達していた。 以上より, 透析導入によって是正された後の維持期収縮期血圧が透析患者の予後を決定する重要な因子と考えられた.

\section{Role of systolic blood pressure in the prognosis of hemodialyzed patients}

Jun Tomita, Genjiro Kimura, Toru Sanai, Yuhei Kawano, Masahito Imanishi, Minoru Kawamura, Shunichi Kojima, Terunao Ashida, Hitoshi Abe, Kaoru Yoshida, Hiroki Yoshimi, Shunroku Baba, Morio Kuramochi, Teruo Omae

Department of Medicine, National Cardiovascular Center

Recently, the cardiovascular mortality rate has increased in hemodialyzed patients. We evaluated the role of blood pressure in determining the prognosis in dialyzed patients. In 195 patients (123 men and 72 women; mean age, $54 \pm 1$ years), who were introduced to hemodialysis therapy in the National Cardiovascular Center between 1977 and 1987, the relationship was studied between blood pressures in both the introduction and maintenance phases and the surviving or death on January 1990. The age was higher ( $61 \pm 2$ vs $50 \pm 2$ years), the occurrence of diabetic nephropathy higher, and systolic blood pressure higher in both the introduction (178 4 vs $167 \pm 2$ $\mathrm{mmHg}$ ) and maintenance (165 \pm 4 vs $147 \pm 2 \mathrm{mmHg}$ ) phases in 46 patients who died within 3 years after starting hemodialysis than in 132 patients who survived more than 3 years. But there were no significant differences in diastolic blood pressures in either the introduction or maintenance phase between the two groups of patients. When diabetic nephropathy was excluded, only systolic blood pressure in the maintenance phase was significantly higher

冨田 純 国立循環器病センター内科 † 565 吹田市藤白台 5-7-1 (06-833-5012)

〔受付: 平成 3 年 6 月 14 日, 受理: 平成 3 年 6 月 22 日〕 
in the death group than in the surviving group. Therefore, based on the systolic blood pressure in the maintenance phase, patients were divided into two groups (HT group : $\geq 160 \mathrm{mmHg}$ and $\mathrm{NT}$ group : $<160 \mathrm{mmHg}$ ), and the cumulative survival rate was compared. Whether all patients, only patients with diabetic nephropathy, or those without diabetic nephropathy were examined, the survival rate was higher in the NT group than in HT group. The patients were also divided into the following three groups based on the changes in systolic blood pressure from the introduction to maintenance phase : HT-NT group whose blood pressure was higher than $160 \mathrm{mmHg}$ at the star; but was reduced below $160 \mathrm{mmHg}$ in the maintenance phase; HT-HT group whose pressure was higher than $160 \mathrm{mmHg}$ in both introduction and maintenance phases; and NT-NT group whose pressure was below 160 $\mathrm{mml} / \mathrm{g}$ in both phases. The cumulative survival rate in the HT-NT group was significantly higher than in the HT-HT group, and was as high as in the NT-NT group. Our results indicate that systolic blood pressure in the maintenance phase, corrected by hemodialysis, is important in determining the prognosis of hemodialyzed patients.

\section{目的}

近年，わが国では透析療法の普及と共に，腎不全によ る死亡率は一旦は減少した。しかし，透析患者数は年及 増加し，1979 年以降，腎不全患者の死亡率は逆に増加す る傾向を示している ${ }^{1)}$. 特に, 透析患者の死因として循環 器疾患による死亡率の増加が目立っている。そこで，透 析息者の予後について導入期扔よび維持期(転院時のみ) に晾ける血圧がどの程度の影響を及ぼしているか検討し た。

\section{万法}

\section{1. 対象}

2977 年から 1987 年の間に当施設で血液透析に導入 し，転院し得た慢性腎不全患者 195 例（男性 123 例，女 性 72 例) を対象とした。年齢は 16 歳から 82 歳で，平均 $53.8 \pm 1.0$ 歳であった。原因疾患別に示すと慢性系球体 腎炎 96 例, 糖尿病性腎症 52 例, 腎硬化症 18 例, 多発性 囊跑腎 8 例，慢性腎孟腎炎 4 例，SLE 3 例，不明 16 例 で放った。

1990 年 1 月における生死についてアンケート調査を 行ったところ回答率は $100 \%$ で，不明例は 1 例もなく， 195 例中観察期間中に死亡したのは 66 例であった（図 1)。死亡例については死亡診断書の第 1 死因を認べた。 全死亡 66 例中，尿毒症 31 例，心血管障害 17 例，感染症 2 例，悪性腫瘍 2 例，その他 8 例，不明 6 例であった。 明らかに循環器疾患以外による死亡例は 4 例と少なく, かつ尿毒症という不明瞭な死因が多かったため, 今回は, 死因についての分析は加えず生死のみについて評価する ことにした。

\section{Risk factors の分析項目}

以上の症例について導入期，維持期の risk factors に ついて調査し，生命予後との関係を分析した。この場合 の導入期とは透析導入前 1 週間以内を，維持期とは導入 後 2 週間以降で, かつ当センターから他院へ転院する直

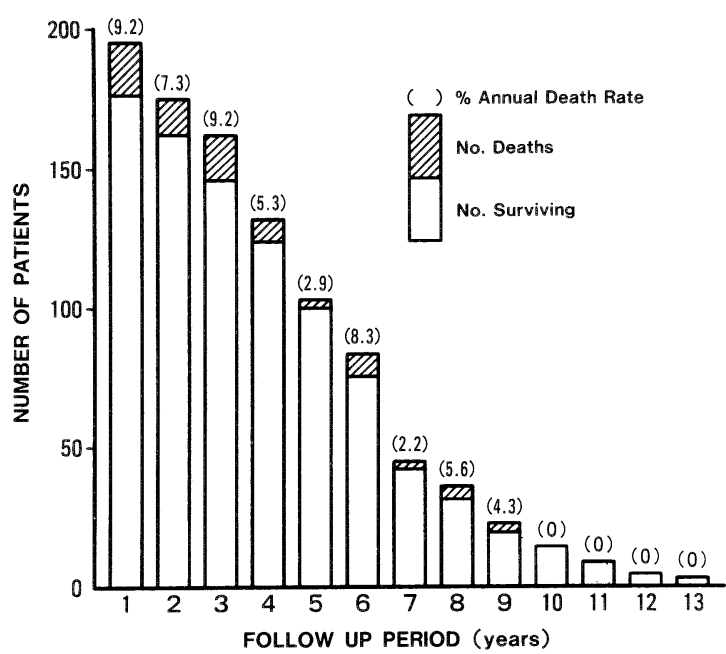

図 1 追跡期間と年間死亡率. 横軸は追跡期間を, 緹軸は下から open column で 1 年毎の生 存数, hatched column で 1 年毎の死亡数 を（）内には年間死亡率を示した。導入 後 3 年までの年間死亡率は 4 年以降の年間 死亡率に比べ高い傾向が見られた。

前とした。

まず，年齢，性別，身長，ドライウェイトを，次に， 原疾患が糖尿病性腎症か否か, 虚血性心疾患, 脳血管障 害, 閉塞性動脈硬化症の既往があるか否か，喫煙の経歴 があるか否かを調査した。また，導入時心電図所見を正 常, 左室肥大 $(\mathrm{Sv} 1+\mathrm{Rv} 5 \geqq 3.5 \mathrm{mV})$ のみ, 軽度の $\mathrm{ST}$ 低 下 $(0.05 \sim 0.1 \mathrm{mV})$ を伴うもの, 高度の ST 低下（ $\geqq 0.1$ $\mathrm{mV})$ を伴うものの 4 段階に分け評価した。導入期および 維持期の臨床検査データとして, 血清尿素窒素 (BUN), クレアチニン $(\mathrm{Cr})$, 尿酸, カルシウム, リン, コレステ ロール，トリグリセリド，HDL-コレステロール，グル コース, 総蛋白, アルブミン, トランスフェリン濃度, 赤血球数，へモグロビン濃度，ヘマトクリット值を測定 
表 導入後 3 年以上生存群と 3 年末満死亡群の比較

\begin{tabular}{|c|c|c|c|}
\hline & 生存群 $(\mathrm{n}=132)$ & 死亡群 $(\mathrm{n}=46)$ & $\mathrm{p}$ \\
\hline 年＼cjkstart齢（歳） & $51 \pm 1$ & $63 \pm 2$ & $<0.0001$ \\
\hline 性 別（男：女） & $86: 46$ & $32: 14$ & NS \\
\hline 身 長 $(\mathrm{cm})$ & $161 \pm 1$ & $159 \pm 1$ & NS \\
\hline ドライウェイト (kg) & $50.5 \pm 0.8$ & $46.1 \pm 1.2$ & $<0.003$ \\
\hline 糖尿病性腎症（\%) & 17.4 & 52.2 & $<0.0001$ \\
\hline 脳血管障害（\%） & 6.1 & 28.3 & $<0.0004$ \\
\hline 閉塞性動脈硬化症（\%) & 2.3 & 10.9 & $<0.005$ \\
\hline 虚血性心疾患（\%） & 8.3 & 21.7 & NS \\
\hline タバコ（\%） & 46.2 & 65.2 & $<0.01$ \\
\hline 心電図 (ST change $0 \sim 3$ ) & $1.1 \pm 0.1 \quad(n=115)$ & $1.6 \pm 0.2 \quad(n=36)$ & $<0.0003$ \\
\hline 導入期 SBP (mmHg) & $167 \pm 2$ & $178 \pm 4$ & $<0.02$ \\
\hline 導入期 DBP (mmHg) & $92 \pm 1$ & $90 \pm 2$ & NS \\
\hline 維持期 SBP (mmHg) & $147 \pm 2$ & $165 \pm 4$ & $<0.0001$ \\
\hline 維持期 DBP (mmHg) & $79 \pm 1$ & $80 \pm 2$ & NS \\
\hline 導入期 BUN/Cr 比 & $10.0 \pm 0.3$ & $11.7 \pm 0.7$ & $<0.005$ \\
\hline 導入期 Albumin $(\mathrm{g} / \mathrm{d} l)$ & $3.7 \pm 0.1 \quad(\mathrm{n}=128)$ & $3.4 \pm 0.1 \quad(n=44)$ & $<0.01$ \\
\hline
\end{tabular}

平均値土標準誤差

した。導入期血圧については, 入院直前に外来で測定し た血圧とし, 維持期血圧については透析日の朝, 透析室 でベッド上安静にて測定した血圧とした。

3 . 分析方法

1) 年間死亡率と累積生存率

全例について年間死亡率（図 1 参照）と累積生存率を 求めた。累積生存率は生命保険数理法に基づいて計算し た.

\section{2 ) 生存群と死亡群の比較}

3 年以上生存した生存群 (132 例) と 3 年未満に死亡し た死亡群 (46 例) に分け臨床像および導入期と維持期の 検査デー夕，血圧について比較した。有意差検定には， 対応のない Student-t 検定および $\chi^{2}$ 検定を用いた。

3 ) 累積生存率の群間比較

全例 195 例, 糖尿病性腎症 52 例, 非糖尿病性腎症 143 例について導入期および維持期収縮期血圧に注目して, さまざまな群に分類し, Kaplan-Meier 法に基づいて累 積生存率を比較した。各群の累積生存率の比較に当たつ ては，年齢をマッチした上で，Cox-Mantel 法によって 有意差を検定した。

\section{結果}

1. 年間死亡率と累積生存率

追跡期間と年間死亡率の関係を調べた (図 1 参照)。導 入後 3 年までの年間死亡率は 4 年以降の年間死亡率に比 べ高い傾向にあった。次に，生命保険数理法に基づいて 累積生存率を求め回帰直線を描いたところ 3 年生存率が $79.9 \%, 5$ 年生存率が $70.8 \%$ となった.

\section{2 . 生存群と死亡群の比較}

各 risk factors について 3 年以上生存した生存群 (132 例) と 3 年末満に死亡した死亡群 (46 例) で比較し, 有 意差を認めた項目を中心に示した(表). 平均年齢は生存 群 $51 \pm 1$ 歳に比べ死亡群 $63 \pm 2$ 歳と有意に高值を示し, 性別に有意差はなかった。原疾患では糖尿病性腎症が死 亡群で $52.2 \%$ と非常に高く, 既往症に関しては, 脳血管 障害, 閉塞性動脈硬化症および, 喫煙歴が死亡群で高率 に認められた。虚血性心疾患には有意差を認めなかった ものの生存群に比し死亡群で高率な傾向にあった。導入 期心電図所見を左室肥大と ST 変化について 4 段階に分 け評価したところ死亡群で心電図変化の程度が強く認め られた。導入期および維持期の検查デー夕に関しては, 死亡群で導入期 $\mathrm{BUN} / \mathrm{Cr}$ 比が高く, 導入期血清アルブ ミン濃度が低值を示した。

収縮期血圧 SBP について注目すると導入期収縮期血 圧は生存群で $167 \pm 2 \mathrm{mmHg}$, 死亡群で $178 \pm 4 \mathrm{mmHg}$, 維持期収縮期血圧は生存群で $147 \pm 2 \mathrm{mmHg}$, 死亡群で $165 \pm 4 \mathrm{mmHg}$ と, いずれの phase でも死亡群は生存群 に比べ収縮期血圧は有意に高値を示した（図 2 ）。

拡張期血圧 DBP に注目すると導入期拡張期血圧は生 存群で $92 \pm 1 \mathrm{mmHg}$, 死亡群で $90 \pm 2 \mathrm{mmHg}$, 維持期拡 張期血圧は生存群で $70 \pm 1 \mathrm{mmHg}$, 死亡群で $80 \pm 2$ $\mathrm{mmHg}$ であった。血液透析により導入期から維持期にか け挔張期血圧は低下するものの, 生存群と死亡群の間に は導入期, 維持期共に有意差を認めなかった(図 2 参照). 生存群と死亡群の間で年齢の因子を除くため年齢を 
マッチした 3 年以上生存群 $(\mathrm{n}=36$, 年齢 $59 \pm 2)$ と 3 年未満死亡群 $(\mathrm{n}=36$, 年齢 $59 \pm 2)$ で収縮期血圧を比 較した。年齢の因子を除いてもなお導入期収縮期血圧 $(164 \pm 4 \mathrm{mmHg}$ vs $178 \pm 5 \mathrm{mmHg}, \mathrm{p}<0.02)$, 維持期収縮 期血圧 $(144 \pm 4 \mathrm{mmHg}$ vs $168 \pm 5 \mathrm{mmHg}, \mathrm{p}<0.0001)$ 共 に生存群に比し死亡群で有意に高值を示した. 次に, 糖 疗病の因子を除くため非糖尿病性腎症例について年齢を マッチした 3 年以上生存群 $(\mathrm{n}=21$, 年齢 $62 \pm 3)$ と 3 年末満死亡群 $(n=21$, 年齢 $62 \pm 3)$ について血圧を比 較した。導入期および維持期拡張期血圧と導入期収縮期 血圧については生存群と死亡群の間で有意差を認めず, 維持期収縮期血圧のみ生存群に比し死亡群で高值を示し た (140土4 mmHg vs $164 \pm 7 \mathrm{mmHg}, \mathrm{p}<0.01)$. 年齢の因 子を補正し糖尿病の因子を除外すると血圧のなかでは維 持期における収縮期血圧のみが生命予後に影響している ことが推察された。

\section{3 。累積生存率の群間比較}

195 例全例を導入期収縮期血圧 $160 \mathrm{mmHg}$ 以上の HT 群と導入期収縮期血圧 $160 \mathrm{mmHg}$ 未満の NT 群に 分け; 年齢をマッチし, HT 群 $(\mathrm{n}=60$, 年齢 $51 \pm 2)$ と $\mathrm{NT}$ 群 $(\mathrm{n}=60$, 年齢 $51 \pm 2)$ について累積生存率を比 較した (図 3 ). 同様に, 維持期収縮期血圧に関しても, 全例を $160 \mathrm{mmHg}$ 以上の $\mathrm{HT}$ 群 $(\mathrm{n}=76$, 年齢 $56 \pm 2)$ と $160 \mathrm{mmHg}$ 末満の $\mathrm{NT}$ 群 $(\mathrm{n}=119$, 年歯 $53 \pm 1)$ に分け累積生存率を比較した。この 2 群間には年齢に有 意差はなくマッチングをしなかった。導入期においても 維持期においても NT 群に比較し HT 群の累積生存率 は有意に低かった。

次に, 糖尿病性腎症例と非糖尿病性腎症例について, 各々維持期収縮期血圧が $160 \mathrm{mmHg}$ 以上の HT 群と $160 \mathrm{mmHg}$ 未満の NT 群に分け年歯をマッチし累積生 存率を比較した。糖尿病性腎症例 (HT 群; $\mathrm{n}=29$, 年 齢 $60 \pm 2, \mathrm{NT}$ 群 ; $\mathrm{n}=23$, 年齢 $59 \pm 3, \mathrm{p}<0.04)$, 非糖尿病性腎症例 (HT 群; $\mathrm{n}=27$, 年齢 $50 \pm 3, \mathrm{NT}$ 群; $\mathrm{n}=54$, 年齢 $52 \pm 2, \mathrm{p}<0.02)$ においても $\mathrm{NT}$ 群 に比較し HT 群では累積生存率は有意に低い結果と

INTRODUCTION PHASE

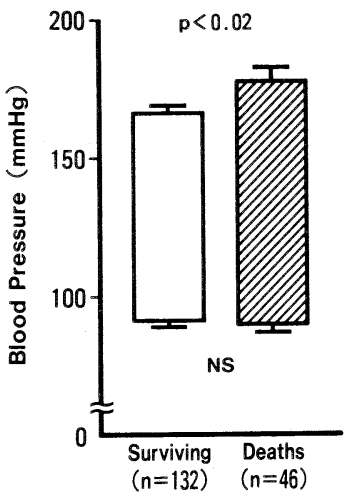

\section{MAINTENANCE PHASE}

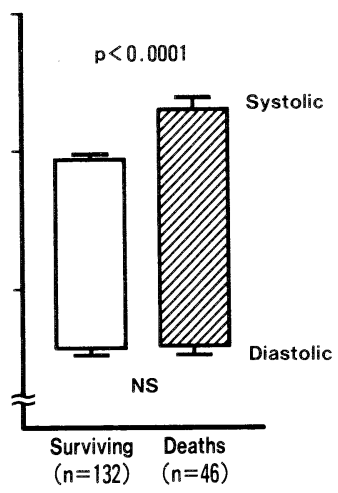

図 2 生命予後に及ぼす血圧の影響. 左が導入期 の血圧，右が維持期の血圧である. Open column は 3 年以上生存群, hatched column は 3 年末満死亡群を, また, columnの 最大值は収縮期血圧, 最小值は拡張期血圧 を表している。

MAINTENANCE PHASE

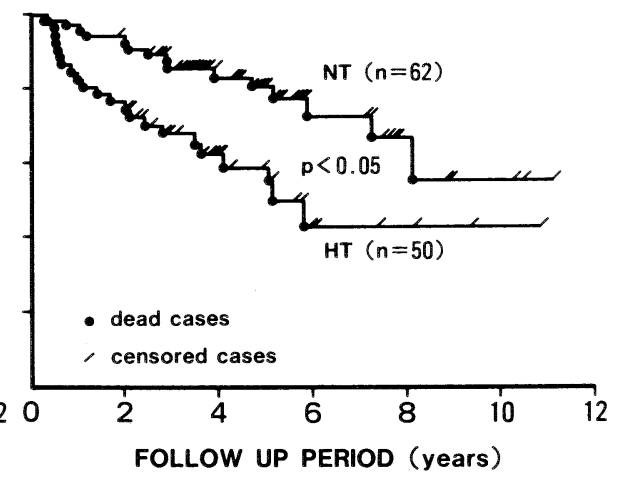

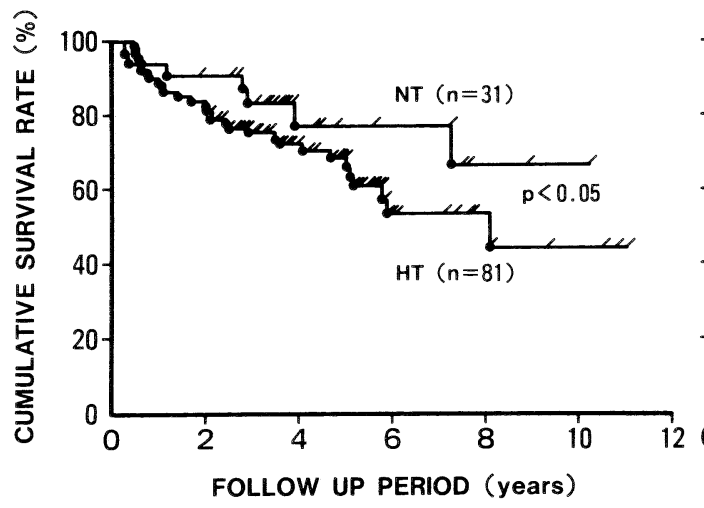

図 3 収縮期血圧の生命予後に及ぼす影響. 収縮期血圧が $160 \mathrm{mmHg}$ 以上を HT 群, $160 \mathrm{mmHg}$ 未満を NT 群とし, Kaplan-Meier 法にて累積生 存率を求めた。左が導入期, 右が維持期の血圧である. 横軸は追跡期間, 縦軸は累積生存率で死亡例を closed cicle, 追跡打ち切り例を/で表し た。 
なった。

最後に，導入期から維持期にかけて収縮期血圧の推移 別に 3 群に分け分析した(図 4)。導入期には収縮期血圧 が $160 \mathrm{mmHg}$ 以上であり，血液透析により維持期には $160 \mathrm{mmHg}$ 未満に改善した症例を $\mathrm{HT} \rightarrow \mathrm{NT}$ 群, 临入期 も維持期も収縮期血圧が $160 \mathrm{mmHg}$ 以上の症例を $\mathrm{HT}$ $\rightarrow \mathrm{HT}$ 群，導入期維持期ともに収縮期血圧が $160 \mathrm{mmHg}$ 未満であった NT $\rightarrow \mathrm{NT}$ 群の 3 群に分け年齢をマッチし 累積生存率求めた $(\mathrm{HT} \rightarrow \mathrm{HT}$ 群 ; $\mathrm{n}=31$, 年齢 $56 \pm$ $2, \mathrm{HT} \rightarrow \mathrm{NT}$ 群 ; $\mathrm{n}=31$, 年齢 $56 \pm 3, \mathrm{NT} \rightarrow \mathrm{NT}$ 群; $\mathrm{n}=31$, 年齢 $56 \pm 3) . \mathrm{HT} \rightarrow \mathrm{NT}$ 群は $\mathrm{HT} \rightarrow \mathrm{HT}$ 群に 比較して累積生存率は有意に高く, $\mathrm{NT} \rightarrow \mathrm{NT}$ 群と同レ ベルまで改善した。また，NT $\rightarrow \mathrm{NT}$ 群は $\mathrm{HT} \rightarrow \mathrm{HT}$ 群 に比較し有意差はないものの累積生存率は高い傾向に あった。これは，導入期に収縮期血圧が高值であっても 血液透析によって血圧がコントロールされると生命予後 に及济すリスクが軽減されることを示していると考えら れた。

考察

透析療法の普及に伴い透析患者数が増加する一方で, 循環器疾患による死亡率も年々増加してきている。透析 患者の予後に対して導入期および維持期（転院時のみ） における血圧がどの程度の影響を及ぼしているか検討し た。

腎不全の原因疾患別にみると慢性系球体腎炎が全体の 約 $1 / 2$, 糖尿病性腎症が $1 / 4$ を占めて招り日本透析療 法学会のデータ (1988 年) と比較するとほぼ一致した結 果が得られた ${ }^{22}$ 。糖㽷病性腎症は予後不良であるという 報告は数多くみられ，我々のデータでも同様の結果を認 めた。近年, 透析患者の死亡率が年及増加の傾向にあり, 糖尿病性腎症のため導入する割合が増えていることをそ の原因の一つに挙げている報告も多い ${ }^{2,3}$. 逆に, 多発性 囊胞腎は長期予後がよいといわれて扔り ${ }^{4)}$, 今回のケー スでも多発性囊胞腎で観察期間中に死亡したのは 8 例中 1 例であった。この死亡した 1 例は透析導入前より重篤 な高血圧があり導入後も血圧のコントロールができず不 幸な転帰をとった症例であった。

年間死亡率について検討してみると, 導入後 3 年まで の年間死亡率は 4 年以降の年間死亡率に比べ高い傾向が 見られた. Santiago ら ${ }^{51}$ は同様の結果を示しており，導 入時に重篤な循環器疾患を持つ患者の多くは導入後 3 年 以内に亡くなっているといっている。また，循環器疾患 による死亡は透析導入後 5,6 年経つとほとんど見られ ないと報告しているものもあるあ. 以上のことから, 我久 も 3 年以上生存した生存群と 3 年末満に死亡した死亡群 に分け検討してみた。まず，透析導入時の年齢は死亡群

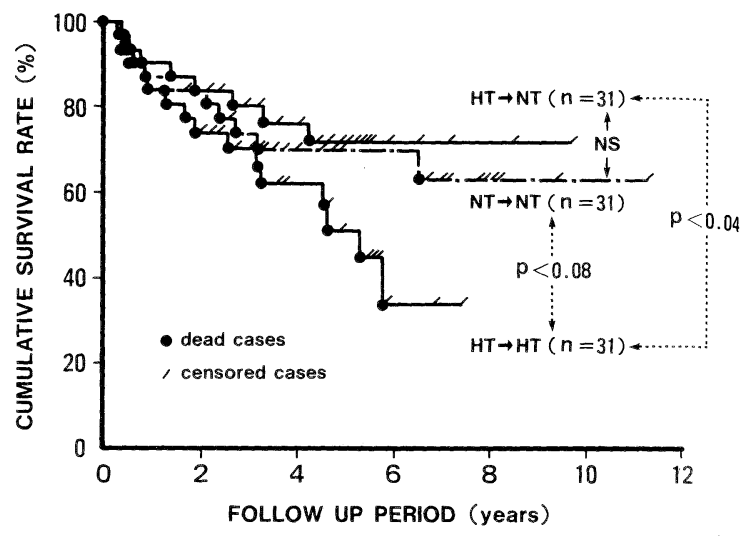

図 4 収縮期血圧の推移別に見た累積生存率. 導 入期には収縮期血圧が $160 \mathrm{mmHg}$ 以上で あり血液透析により維持期には 160 $\mathrm{mmHg}$ 未満に改善した症例を $\mathrm{HT} \rightarrow \mathrm{NT}$ 群，導入期も維持期も収縮期血压が 160 $\mathrm{mmHg}$ 以上の症例を $\mathrm{HT} \rightarrow \mathrm{HT}$ 群，導入 期, 維持期共に収縮期血圧が $160 \mathrm{mmHg}$ 末 満だった $\mathrm{NT} \rightarrow \mathrm{NT}$ 群の 3 群に分け $\mathrm{Ka}$ plan-Meier 法により累積生存率を求め た。横軸は追跡期間, 縦軸は累積生存率で 死亡例を closed cicle, 追跡打ち切り例を/ で表した。

で有意に高かった。透析導入時の年齢が高いほど死亡率 が高く, 循環器疾患による死亡も多いことはすでに明ら かとなって扔り ${ }^{6,7)}$ ，その原因の一つとして年齢と共に動 脈硬化性病変が進行していることがあげられる。年れ故, 血圧の長期予後に及涩す影響を検討するにあたり年齢補 正ないしは年齢マッチが要求されるのは当然である.

循環器疾患による死亡に関係する動脈硬化性病変とし て透析導入時の脳血管障害, 閉塞性動脈硬化症, 虚血性 心疾患の有無と生死との関係について検討した。脳血管 障害の既往や閉塞性動脈硬化症を有する透析患者は 3 年 未満に亡くなる傾向が強かった。虚血性心疾患（心筋梗 塞や狭心症）の既往を有する透析患者の頻度は 3 年以上 生存した群と 3 年末満に死亡した群に有意差を認めな かった。しかし， 5 年以上生存した群と 5 年末満に死亡 した群で比較したところ，5年未満に死亡した群に虚血 性心疾患の既往を有する透析患者の頻度は高い傾向が見 られた $(\mathrm{p}<0.05)$ 。また， 3 年末満に死亡した群で心電 図上 ST 変化が強く認められた。透析導入時，心電図に 肥大性変化や虚血性変化を認める患者に循環器疾患によ る死亡の頻度が高いといわ机て抢り ${ }^{6,8)}$, 我々のデー夕で も一致した結果が得られた。

動脈硬化性病変が透析を始めることによって促進され るか否かは未だ意見の分かれるところであるが ${ }^{4,6,7,9)}$, 高 血圧が透析患者の循環器疾患による死亡に深く関わって 
いることはすでに多数の報告があり，高血圧が透析患者 の動脈硬化を促進させるためと考えられている ${ }^{5 \sim 7)}$.ま た，猰煙は透析患者（特に高血圧を有するもので）の動 脈硬化の促進因子として重要視されており ${ }^{10)}$, 我々の データとも一致した。高血圧の予後に及ぼす影響につい て我々は，導入期血圧と維持期血圧をそれぞれ収縮期血 圧と㠉張期血圧に分け検討した。拡張期血圧は導入期と 維持期のいずれの時期においても生存群と死亡群とで差 は認的なかった。しかし，収縮期血圧では導入期と維持 期，共に血圧の高い群の予後は不良であった，年をとる と共に血圧が高くなってくることは明らかであるため, 年齢定マッチして同様に検討したがやはり収縮期血圧の 高い群で生存率は低かった。これまでの報告と比較する と, 収縮期血圧と拡張期血圧別では拡張期血圧に有意差 を認的ることが多く ${ }^{11)}$ ，中には収縮期血圧には有意差を 認めなかったとする報告もある ${ }^{12)}$ ここれらの報告は,いず れも導入時点の血圧（高血圧の既往を含む）について評 価をしていたままた，長期に亘る透析患者の血圧につい ては 10 年以上生存した透析患者には拡張期血圧が高い 症例はいなかったと報告しているものも見受けられ る 別に検討したものは今までになく，これによると導入時 に血圧が高くても導入後血圧をコントロール（減塩食, 降圧剤の使用を含む) することによって高血圧の長期予 後に及ぼす影響が改善されると期待された。ただし，糖 尿病性腎症患者について収縮期血圧を導入期から維持期 への推移別に検討してみると, 大部分は導入期も維持期 も血圧が高いままであることが判る。従って，導入期， 維持期とも収縮期血圧の高い群で予後不良な理由の一つ として，この群に糖尿病性腎症が多く含まれていること も否定できない。

血液生化学デー夕上では, 導入時における $\mathrm{BUN} / \mathrm{Cr}$ 比と血清アルブミン濃度のみ有意差を認めた。導入時に おいて BUN が高い状態は，組織異化が穴進しており栄 養状態不良を反映しているという報告がある ${ }^{13)}$. 我々の データでも導入時 $\mathrm{BUN} / \mathrm{Cr}$ 比が死亡群で有意に高く, 同様の理由が考えられた。逆に，維持期において BUN/ $\mathrm{Cr}$ が低いと循環器疾患による死亡のうちでも特に脳卒 中の発症が多く，これは蛋白摂取量が少ないことを反映 しているといっているものもある ${ }^{14)}$ ，血清アルブミン濃 度は 1 年以内に死亡している症例で特に低い傾向が見ら れ，全身状態が不良であることを反映していると考えら れた。

死因については今回検討していないが，日本透析療法 学会のデータから判るように透析患者の死因の中で循環 器疾患による死亡が占める割合は高く，また年々増加傾
向にある。その増加の原因として透析導入患者の高齢化 や糖尿病性腎症の増加，また心血管系を中心とした重篤 な合併症や複数の合併症をもつ透析導入患者の増加が考 えられている ${ }^{3)}$. 今回の我々の結論がそのまま循環器疾 患による死亡にも当てはめられるかどうかは今後さらに 検討していきたいと思う。

結論

透析患者の生命予後に及ぼす導入期，維持期における 血圧の影響を検討した。

1. 糖尿病，非糖尿病例とも収縮期血圧が高い群で予 後不良であった。

2. 導入期収縮期血圧より維持期収縮期血圧の方が生 命予後に及ぼす影響が大きかった。

3 . 透析患者では拡張期血圧は, 生命予後に余り関係 していないと考えられた。

従って，透析患者の血圧管理に扔いては拡張期血圧よ りも収縮期血圧，導入期よりも維持期の血圧の方が生命 予後に強く関係していると考えられた。

\section{文献}

1）厚生省：人口動態統計，1988

2）小高通夫：我が国の透析療法の現況。透析会誌 22 ： 221-304, 1988

3) Collins AJ, Hanson G, Umen A, Kjellstrand C, Keshaviah $\mathrm{P}$ : Changing risk factor demographics in end-stage renal disease patients entering hemodialysis and the impact on long-term mortality. Am J Kidney Dis 15 : 422-432, 1990

4) Neff MS, Eiser AR, Slifkin RF, Baum M, Baez A, Gupta S, Amarga E : Patients surviving 10 years of hemodialysis. Am J Med 74 : 996-1003, 1983

5) Santiago A, Chazan JA : The cause of death and co-morbid factors in 405 chronic hemodialysis patients. Dialysis Transpl 18: 484-488, 1989

6) Esposti ED, Boero R, Chiarini C, Negroni D, Quarello F, Santoro A, Sturani C, Zuccala C, Piccoli G, Zucchelli P : Blood pressure behavior in hemodialysis patients treated for 10 years. Intern J Arti Organs 6 : 121-126, 1983

7) Vincenti F, Amend WJ, Abele J, Feduska NJ, Salvatierra $\mathrm{O}$ : The role of hypertension in hemodialysis-associated atherosclerosis. Am J Med 68:363-369, 1980

8) Ritz E, Strumpf C, Katz F, Wing AJ, Quellhorst $\mathrm{E}:$ Hypertention and cardiovascular risk factors in hemodialyzed diabetic patients. Hypertension 7 
(Suppl II) : II-118-II-124, 1985

9) Lindner A, Charra B, Sherrard DJ, Scribner BH :

Accelerated atherosclerosis in prolonged maintenance hemodialysis. N Engl J Med 290 : 697-701, 1974

10) Haire HM, Sherrard DJ, Scardpane D, Curtis FK, Brunzell JD : Smorking, hypertension and mortality in a maintenance dialysis population. Cardiovascular Med 3 : 1163-1168, 1978

11) Oksa H, Pasternack A, Pasanen $M$ : Serum urea-creatinine ratio as a prognostic index in hemodialysis patients. Clin Nephrol 27 : 125-130, 1987
12) Chester AC, Schreiner GE: Hypertension and hemodialysis. Trans Am Soc Intern Organs 116 : 36-42, 1978

13) Lowrie EG, Laird NM, Paker TF, Sargent A : Effect of the hemodialysis prescription on patient morbidity. Report from the National Cooperative Dialysis Study. N Engl J Med 305:1176-1181, 1981

14) Degoulet $P$, Legrain $M$, Reach I, Aime F, Devries C, Rojas P, Jacobs C : Mortality risk factors in patients treated by chronic hemodialysis. Nephron 31 : 103-110, 1982 